\section{Effect of Different Doses of Synthetic Parathyroid Hormone (1-34) on Bone around Implants:a Preclinical Rat Model}

\author{
Carlos Eduardo Secco Mafra ${ }^{1}$, Marcelo Sirolli', Marília Cabral \\ Cavalcanti ${ }^{1}$, Rodrigo Basílio Albuquerque dos Santos ${ }^{1}$, Cláudio \\ Mendes Pannuti ${ }^{1}$, Giuseppe Alexandre Romito ${ }^{1}$, João Batista César Neto ${ }^{1}$
}

'Department of Stomatology, Division of Periodontology, School of Dentistry, USP- Universidade de São Paulo, São Paulo, SP, Brazil

Correspondence : João Batista César Neto, Av. Professor lineu Prestes, 2227, 05508-000 São Paulo-SP, Brazil. Tel : +55-11-3091-7833. e-mail: jbcesarneto@usp.br

\begin{abstract}
The aim of this study was to evaluate the effect of a lower dose of parathyroid hormonePTH (1-34) on osteogenic potential of bone healing around titanium implants inserted into the tibia of rats. A blind parallel study was conducted in 45 adult male Wistar rats. Each rat received one titanium implant $(4.5 \times 2.2 \mathrm{~mm})$ and was randomly assigned to receive subcutaneous injections, three times/week for 30 days, of the following treatments: group $1-40 \mu \mathrm{g} / \mathrm{kg}$ of PTH (1-34) ( $=15) ;$ group 2 - $2 \mu \mathrm{g} / \mathrm{kg}$ of PTH (1-34) $(n=15)$ and; group 3 - only the vehicle required for hormone dissolution $(n=15)$. Thirty days after surgery, the animals were sacrificed and specimens containing the implant and the surrounding bone were removed and processed for non-decalcified sections. The sections were evaluated according to the following histometric parameters: proportion of mineralized tissue (PMT) adjacent to the implant threads ( $500 \mu \mathrm{m}$ band); bone filling within the limits of the threads (BF) and; bone-to-implant contact (BIC). For the cortical region, both hormone dosages (groups 1 and 2) promoted better results, for all parameters, when compared to control group $(p<0.05)$. Similar results were observed for the BF parameter in the cancellous region $(p=0.0394)$. Therefore, systemic administration of PTH (1-34) stimulates bone formation around titanium implants, even at low doses.
\end{abstract}

\author{
Key Words: parathyroid \\ hormone (1-34); dental \\ implants; osseointegration;
} wistar rats; bone remodeling.

\section{Introduction}

Oral rehabilitation with osseointegrated titanium implants is safe and present high success and survival rates in the long term (1). However, some factors may contribute to implant failure, such as general health, smoking, bone quality, bone grafting, surgical trauma, immediate loading, implant surfaces characteristics and bacterial contamination (2).

Poor bone quality may affect the predictability of implant rehabilitations and may be associated with less primary stability and decreased capacity to absorb masticatory forces (3). Some alternatives, such as modifications on titanium surface and implant design (4), have been investigated as an attempt to increase bone quality around implants and overcome these limitations. However, few studies have investigated Parathyroid hormone (PTH), a drug that can stimulate a more intense anabolic bone response $(5,6)$.

PTH is used for the treatment of osteoporosis due to its action in controlling the metabolism of organic calcium and phosphate (5). Bone remodeling occurs because PTH controls the flow of these minerals in bone and kidney. In addition, PTH (1-34) promotes bone resorption if the administration is intermittent, with a high anabolic response to the bone tissue (7).

In dental field, studies have shown that intermittent administration of PTH (1-34) significantly reduces bone loss in normal (8) and ovariectomized rats (9). Also, the intermittent administration of PTH (1-34) can prevent trabecular bone resorption around implants as well as recover part of bone volume lost after ovariectomy rats (9). Skripitz et al. (10) showed that PTH seems to prevent bone resorption by stimulating osteoblasts. It is also considered more effective when compared with inhibitors of bone resorption such as alendronate, risedronate, etidronate and raloxifene (5). Futhermore, PTH (1-34) did not increase the incidence of tumors, has no mutagenic effect and presents very low incidence of side effects $(5,11)$.

Mair et al. (12) showed that PTH (1-34) promotes an intense osteogenic effect, increasing the amount of bone around titanium implants. Despite these interesting findings, animal studies have used doses based on studies of carcinogenesis in rats $(13,14)$, which are about 100 to 200 times higher than doses used clinically in humans. Clinical studies have used daily applications of $20 \mu \mathrm{g}$ (5) or $40 \mu \mathrm{g}$ (15) of PTH (1-34) (values around 0.3 to $0.7 \mathrm{mg} / \mathrm{kg} /$ day).

Thus, the aim of this study was to test if lower doses of PTH (1-34), close to the ones administered clinically in patients, could favor osteogenic potential on bone healing around titanium implants inserted into tibia of rats.

\section{Material and Methods}

Animals

Forty-five male adult Wistar rats, with mean age of 
three months, weight $280 \mathrm{~g}$ to $330 \mathrm{~g}$, were used in this study. The animals were kept in plastic cages with access to food and water ad libitum throughout the experimental period. A 12/12 $\mathrm{h}$ day-night cycle was adopted and the environment had controlled humidity and temperature. The research protocol was approved by the University of São Paulo Dentistry School Animal Care and Use Committee (CEUA) (no. 169/2012).

\section{Experimental Design}

All animals received a titanium implant in the right tibia. After implant placement, the animals were randomly assigned to one of the three experimental groups: Group $1(n=15)$ - subcutaneous intermittent doses of PTH (134) $(40 \mu \mathrm{g} / \mathrm{kg}$, per injection), three times a week; Group $2(n=15)$ - subcutaneous intermittent doses of synthetic PTH (1-34) (2 $\mu \mathrm{g} / \mathrm{kg}$, per injection), three times a week; Group 3 - subcutaneous injections of saline solution three times a week.

\section{Surgical Procedures}

All animals received a screw-shaped titanium implant, with $4.5 \mathrm{~mm}$ in length and $2.2 \mathrm{~mm}$ in diameter. Before surgery, the animals were weighed, and according to their body weight, were anesthetized with ketamine solution (50 $\mathrm{mg} / \mathrm{kg}$ ) and xylazine $(10 \mathrm{mg} / \mathrm{kg}$ ) (respectively Francotar and is Virbaxil; Virbac do Brasil Indústria e Comércio, Roseira, SP, - Brazil), intramuscularly. After that, the surgical sites were shaved and disinfected with an iodine solution. With a \# 15 scalpel blade, an incision of approximately $1.5 \mathrm{~cm}$ was performed, providing exposure of muscle tissue, which was elevated, allowing access to the tibiae. A bicortical bed was prepared with a lancet bur and a $2.0 \mathrm{~mm}$ drill $(800 \mathrm{rpm})$. The implants were placed manually until final stabilization in both corticals. The muscular sutures were made with an absorbable suture $\left(\right.$ Vicryl$^{\circledR}$, Johnson \& Johnson, São José dos Campos, SP, Brazil) and with a 5-0 monofilament nylon the surficial tissues were sutured (Ethicon ${ }^{\circledR}$, Johnson \& Johnson). Then, an iodine solution was applied to the surgical area and the animals received a single-dose of intramuscular antibiotic (Pentabiótico ${ }^{\circledR}$, Whitehall LTDA, São Paulo, SP, Brazil) ( $1 \mathrm{~mL} / \mathrm{kg})$. The animals were sacrificed with a ketamine/xylazine overdose (respectively $148 \mathrm{mg} / \mathrm{kg}$ and $30 \mathrm{mg} / \mathrm{kg}$ ) 30 days after surgery. After that, the experimental tissues were removed for histological preparation.

\section{Histologic Processing and Histometric Analysis}

After euthanasia of the animals, the specimens (implant + surrounding bone) were removed in blocks and placed in neutral buffered formalin $4 \%$ for $48 \mathrm{~h}$. After fixing and washing with water, the blocks were dehydrated in ethyl alcohol solution in ascending scale of concentration (60\% to $100 \%)$ under constant stirring. The specimens were finally infiltrated with crescent solutions of methyl methacrylate resin (50\% to 100\%) (Fluka Chemie AG, Buchs, Switzerland). The longitudinal sections were made perpendicularly to the implant. Initially, sections of $500 \mu \mathrm{m}$ were obtained with a precision saw (Exakt Saw band system $300 \mathrm{CP}$, Exakt Technologies, Oklahoma, OK, USA) equipped with a tungsten carbide blade. Then, the sections were attached to acetate slides, and polished using a polishing machine (Knuth -Rotor -3, Struers, Copenhagen, Denmark) until a thickness of approximately $70-80 \mu \mathrm{m}$ (of the central region of the implant). The histological sections were stained with Stevenel's Blue and Alizarin S red (16).

Digital images were acquired using a light microscope connected to a digital camera (Olympus BX60 optical microscope, Olympus Tokyo, Japan). After that, a blind examiner used a software for histometric analysis (Image ${ }^{\circledR}$, Media Cybernetics, Silver Spring, MD, USA) and evaluated the following histometric parameters (in percentage): boneto-implant contact (BIC - linear measurements), bone filling within the limits of the implant threads (BF - point counting technique) and, the proportion of mineralized tissue in a 500 $\mu \mathrm{m}$ band adjacent to the implants (PMT - point counting technique). The parameters were evaluated, as previously described by Nociti Junior et al. (17) and César-Neto et al. (18), separately for cortical and cancellous bone.

\section{Statistical Analysis}

The normal distribution was tested using the Kolmogorov-Smirnov test and the null hypothesis was tested using analysis of variance (ANOVA) for cortical and cancellous regions separately. A Bonferroni test was used when differences between the tree groups were found.

\section{Results}

\section{Histological Description}

None of the 45 animals included in the surgery died before the end of the experimental period ( 30 days after the surgery). All samples showed integration of the implant to the surrounding bone. Bone-to-implant contact and bone filling of the threads were observed in all specimens. All groups also presented newly-formed with histological pattern similar to the one observed for original bone. In the cancellous bone region, some adipose tissue could be observed around the implant. This finding is explained due to the characteristics of the sample used for the study (rats' tibiae).

\section{Histometric Results}

Figure 1 is a composite image of photomicrographs illustrating the histologic aspect of PMT for each group. Figure 2 is a composite image of photomicrographs 
illustrating the histologic aspect of $\mathrm{BIC}$ and $\mathrm{BF}$ parameters for each group in cortical bone. Figure 3 is a composite image of photomicrographs illustrating the histologic aspect of $\mathrm{BIC}$ and $\mathrm{BF}$ parameters for each group in cancellous bone.

For the histometric parameter PMT in the cortical region, both concentrations of PTH (1-34) (Groups 1 and 2) positively influenced bone density when compared to
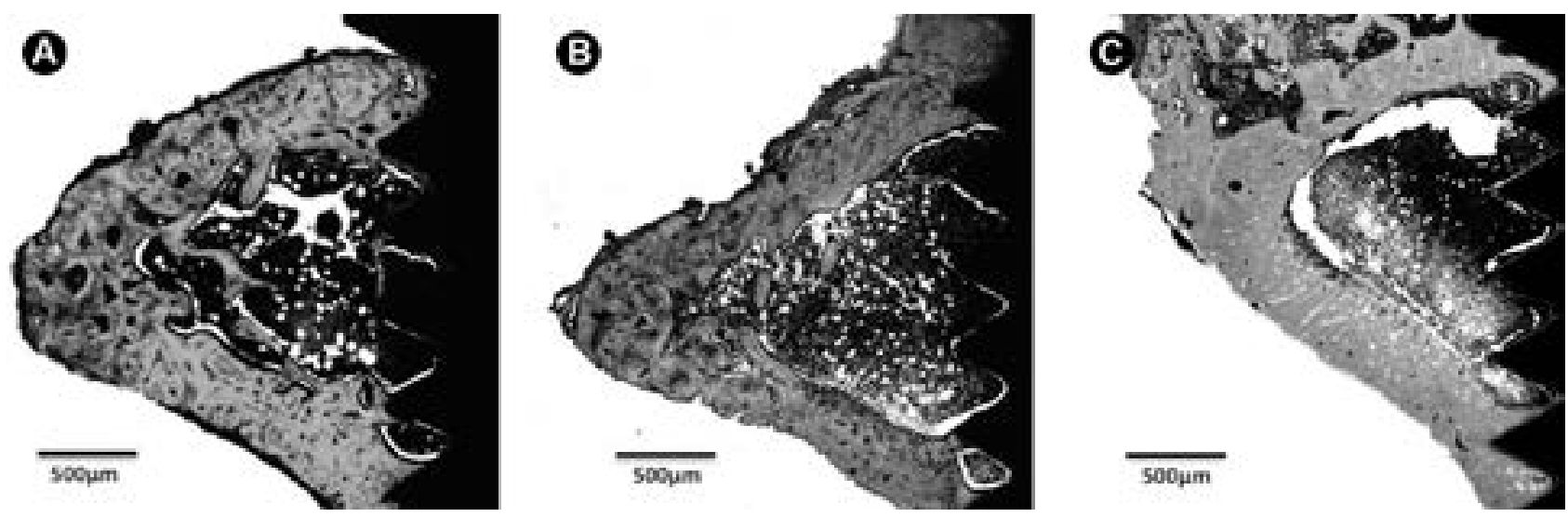

Figure 1. Photomicrographs illustrating the histologic aspect of PMT parameter for each group. (A) Group 1; (B) Group 2; (C) Group 3. (Stevenel blue and Alizarin red; bar $=500 \mathrm{~mm}$ ).
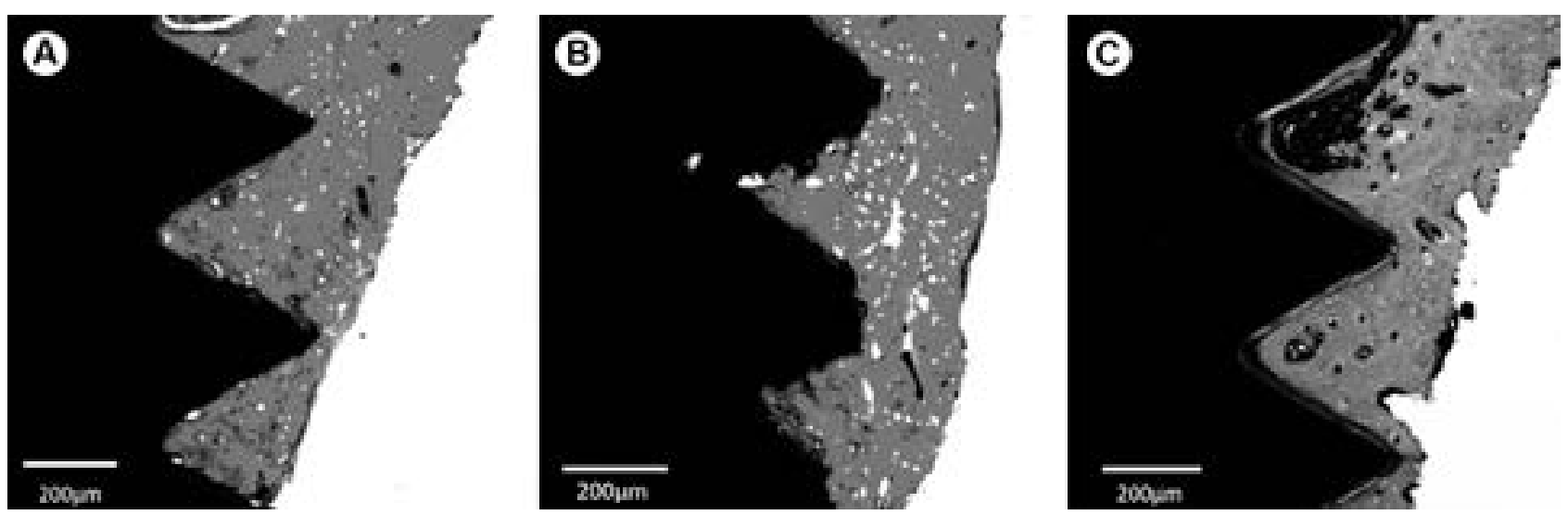

Figure 2. Photomicrographs illustrating the histologic aspect of BIC and BF parameters for each group in cortical bone. (A) Group 1; (B) Group 2; (C) Group 3. (Stevenel blue and Alizarin red; bar = $200 \mathrm{~mm}$ ).
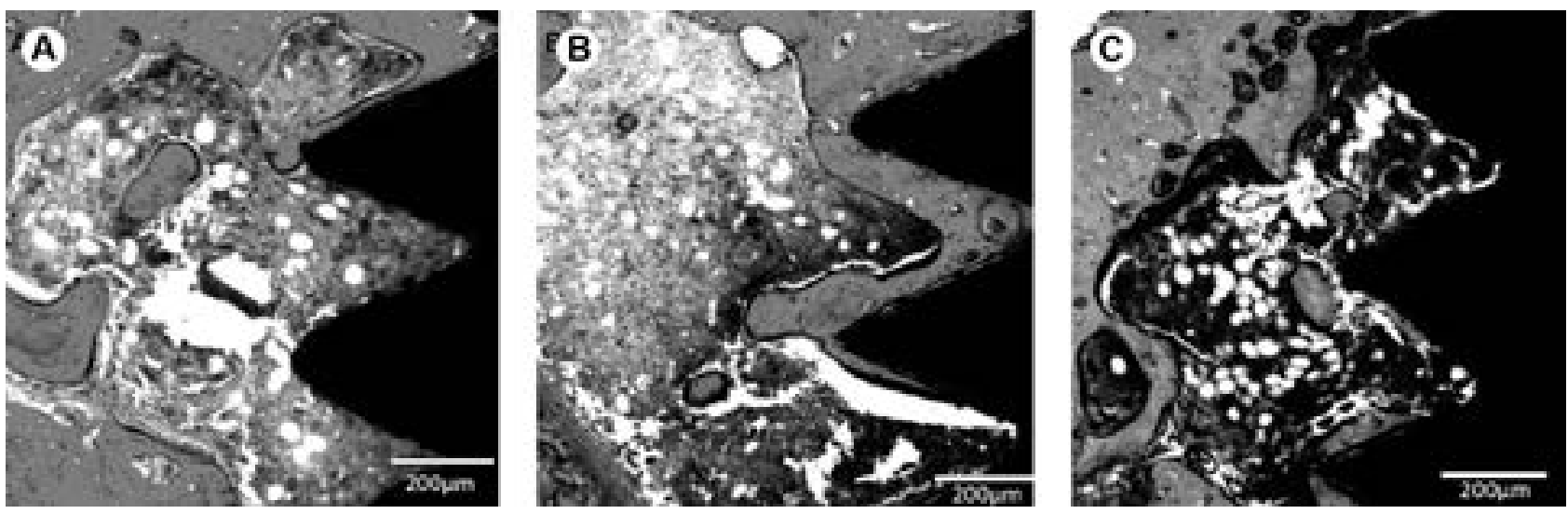

Figure 3. Photomicrographs illustrating the histologic aspect of BIC and BF parameters for each group in cancellous bone. (A) Group 1; (B) Group 2; (C) Group 3. (Stevenel blue and Alizarin red; bar = $200 \mathrm{~mm}$ ). 
the control group (Group 3) $(p<0.05)(A N O V A / B o n f e r r o n i$ post-test, $\alpha=5 \%$ ). In the cancellous bone, no differences between groups were observed ( $p>0.05$ ). Representative averages of each group, their standard deviations (SD) and the results of the statistical analysis are shown in Table 1.

A similar aspect was observed with respect to bone filling within the threads (BF) in the cortical region. No difference was detected when comparing Group $1(40 \mu \mathrm{g} /$ $\mathrm{kg}$ of PTH) and Group 2 ( $2 \mu \mathrm{g} / \mathrm{kg}$ of PTH) ( $>>0.05)$. However, these groups showed higher mean values when compared to control group, and these differences were statistically significant $(p<0.05)$ (ANOVA, post-test Bonferroni $\alpha=5 \%$ ). Similar results were observed for cancellous region, i.e. no differences between groups 1 and 2 ( $p>0.05$ ), which significantly differ from control (group $3 ; p=0.0394$ ) (Table 1).

PTH (1-34) also positively influenced the parameter BIC in the cortical region, similarly to the previously described parameters. The mean values presented by both groups 1 ( $40 \mu \mathrm{g}$ of PTH) and 2 ( $2 \mu \mathrm{g}$ of PTH) were higher than those presented by the control group $(p<0.05)$ (ANOVA, post-test Bonferroni $\alpha=5 \%$ ). In the cancellous bone, no differences between the groups were observed ( $p>0.05$ ) (Table 1).

Table 1. PMT (Percentage of mineralized tissue), BF (Bone filling within the limits of the threads) and BIC (bone-implant-contact) parameters reported for each region (cortical or cancellous) and groups

\begin{tabular}{lcc}
\hline Parameters & Cortical & Cancellous \\
\hline PMT & & \\
Group 1 & $79.57 \pm 5.04 \mathrm{a}$ & $10.37 \pm 6.69 \mathrm{a}$ \\
Group 2 & $75.98 \pm 7.90 \mathrm{a}$ & $12.17 \pm 7.10 \mathrm{a}$ \\
Group 3 & $72.85 \pm 5.32 \mathrm{~b}$ & $10.25 \pm 10.2 \mathrm{a}$ \\
$p$-value & $<0.005$ & 0.1994 \\
BF & & \\
Group 1 & $74.46 \pm 8.19 \mathrm{a}$ & $21.15 \pm 10.7 \mathrm{a}$ \\
Group 2 & $74.48 \pm 7.30 \mathrm{a}$ & $22.24 \pm 9.40 \mathrm{a}$ \\
Group 3 & $62.52 \pm 7.11 \mathrm{~b}$ & $15.82 \pm 4.55 \mathrm{~b}$ \\
$p$-value & $<0.0001$ & 0.0394 \\
BIC & & \\
Group 1 & $74.71 \pm 10.5 \mathrm{a}$ & $27.73 \pm 8.40 \mathrm{a}$ \\
Group 2 & $73.65 \pm 9.85 \mathrm{a}$ & $28.43 \pm 8.35 \mathrm{a}$ \\
Group 3 & $42.99 \pm 21.21 \mathrm{~b}$ & $23.42 \pm 7.87 \mathrm{a}$ \\
$p$-value & $<0.0001$ & 0.1699 \\
\hline
\end{tabular}

Data are described as Mean \pm Standard Deviation in percentage. Different lowercase letters (columns) indicate statistically significant differences ( $p<0.05$ - ANOVA / Bonferroni post-test, $\alpha=5 \%$ ).

\section{Discussion}

The present study evaluated the effect of PTH (1-34) on bone healing around titanium implants, and additionally assessed whether an alternative dose, lower than the ones investigated in previous studies, would also exert biological effects. Our results demonstrated an osteoanabolic effect of PTH (1-34), for both concentrations; in all histometric parameters investigated i.e. PMT, BF and BIC. Moreover, no statistically significant differences were observed between the groups that received PTH (1-34) injections, suggesting that, at least for the present experimental model, a similar effect was observed for the two experimental dosages. These results allow us to speculate that doses lower than the ones commonly used in studies with rats may also have osteoanabolic effect, and it might have future potencial clinical use.

Most of the studies investigating the impact of PTH (134) on bone healing around titanium implants evaluated its effect in animals with conditions that lead to systemic bone loss e.g. osteoporosis (19), aging (12) and smoking (20). The present study investigated young normoreactive rats and demonstrated that PTH (1-34) is able not only to compensate the negative effects of bone catabolic conditions (e.g. osteoporosis, diabetes and smoking) but also enhance bone formation in animals without these conditions.

In implantology field, the potential therapeutic use of PTH (1-34) suggest that its administration might decrease the time necessary for implant-supported rehabilitations in healthy patients or could increase the success chance in challenging situations, as poor bone quality and quantity, and also for treating osteonecrosis from bisphosphonates. Such hypothesis is specially emphasized by the results concerning the low doses of PTH (1-34) $(2 \mu \mathrm{g} / \mathrm{kg})$, used in the present study, since the low is the dosage and the administration period, the low is the chance of side effects.

Considering possible side effects of PTH, some studies about carcinogenesis in rats $(21,22)$ tested different doses: $1.2 \mathrm{nmol} / \mathrm{kg}(5 \mu \mathrm{g} / \mathrm{kg}), 7.2 \mathrm{nmol} / \mathrm{kg}(30 \mu \mathrm{g} / \mathrm{kg})$ and 18.3 $\mathrm{nmol} / \mathrm{kg}(75 \mu \mathrm{g} / \mathrm{kg})$ of body weight. It was observed that doses higher than $30 \mu \mathrm{g} / \mathrm{kg}$, administered for over than 20 months, showed an increased incidence of adverse effects. Osteosarcoma was the most common side effect, followed by osteoblastic focal hyperplasia, osteoblastoma, osteoma and skeletal fibrosarcomas. The present study used doses of $2 \mu \mathrm{g} / \mathrm{kg}$ that are closer to the one used clinically in humans and approved by the FDA ( $20 \mu \mathrm{g} /$ day).

Some studies used the dose of $40 \mathrm{mg} / \mathrm{kg}$ in rats $(23,24)$, which provided subsidies for using this dose. Our research group decided to use 3 times a week regimen, since our objective was to test an administration protocol with lower chances of inducing side effects. One interesting study that support the present administration protocol was conducted 
by Barros et al. (8). Using systemically healthy adult rats, they demonstrated that $40 \mu \mathrm{g} / \mathrm{kg}$ of PTH (1-34) applied every two days, had a protective effect against alveolar bone loss in ligature-induced periodontitis. Despite these findings, it is important to emphasize that the higher dosage used in the present study (i.e. $40 \mu \mathrm{g} / \mathrm{kg}$ ) and the alternative lower dosage i.e. $(2 \mu \mathrm{g} / \mathrm{kg})$ were not tested in these experimental conditions yet.

Mair et al. (12) used females rats to assess the effect of aging (2 months versus 8 months) and PTH (1-34) (dosage of $60 \mu \mathrm{g} / \mathrm{kg}$, three times a week) on bone healing around titanium implants. PTH (1-34) influenced the proportion of mineralized tissue (in cancellous region) for both groups. However, it did not influence BIC. Our results differ from Mair et al. (12), since we observed a positive influence of PTH (1-34) on BIC that was statistically significant. The differences between the results may be at least partially explained by the number of groups, statistical analysis, implant design, titanium surface treatment and the dosage of PTH (1-34) employed.

According to Thomas (25), the administration of PTH in rats stimulate the formation of bone in both periosteal side and endosteal sides, which results in an increase of the cortical diameter and hence biomechanical properties. Such data support the results of our findings, where the effect of PTH (1-34) seems to be stronger in the cortical region, since statistically significant differences were observed for all histometric parameters evaluated in this region. For the cancellous region, only BF showed statistically significant differences in the groups receiving PTH (1-34).

The present study suggests that PTH (1-34) can be used to optimize implant treatment, even with lower doses and for shorter time. Besides, using lower doses, we can, substantially, reduce the risk of osteosarcoma, since it is dose and time dependent. According to these data, our work aim to apply PTH (1-34) , systemically, just during the time of the implant treatment in lower doses, to stimulate bone formation and targeting a significant reduction of side effects.

\section{Resumo}

0 objetivo deste estudo foi avaliar o efeito de uma menor dose de PTH (1-34) sobre o potencial osteogênico da cicatrização óssea ao redor de implantes de titânio inseridos na tibia de ratos. Um estudo paralelo cego foi conduzido em 45 ratos Wistar machos adultos. Cada rato recebeu um implante de titânio $(4,5 \times 2,2 \mathrm{~mm})$ e foi aleatoriamente designado para receber injeções subcutâneas, três vezes / semana por 30 dias, dos seguintes tratamentos: grupo $1-40 \mu \mathrm{g} / \mathrm{kg}$ de PTH (1-34) $(\mathrm{n}=15)$; grupo $2-2 \mu \mathrm{g} /$ $\mathrm{kg}$ de PTH (1-34) $(\mathrm{n}=15)$ e; grupo 3 - apenas o veículo necessário para a dissolução do hormônio $(n=15)$. Trinta dias após a cirurgia, os animais foram sacrificados e os espécimes contendo o implante e o osso ao redor foram removidos e processados para cortes não descalcificados. As seções foram avaliadas de acordo com os seguintes parâmetros histométricos: proporção de tecido mineralizado (PTM) adjacente aos fios do implante (banda de $500 \mu \mathrm{m}$ ); preenchimento ósseo dentro dos limites dos fios (P0) e; contato osso-implante (COI). Para a região cortical, ambas as dosagens hormonais (grupos 1 e 2) promoveram melhores resultados, para todos os parâmetros, quando comparados ao grupo controle $(p<0,05)$. Resultados semelhantes foram observados para o parâmetro PO na região esponjosa $(p=0,0394)$. Portanto, a administração sistêmica de PTH (1-34) estimula a formação óssea ao redor de implantes de titânio, mesmo em doses baixas.

\section{Acknowledgments}

This study was financed in part by the Coordenação de Aperfeiçoamento de Pessoal de Nivel Superior-Brasil (CAPES) - Finance Code 001

\section{References}

1. Moraschini V, Poubel LA, Ferreira VF, Barboza Edos S. Evaluation of survival and success rates of dental implants reported in longitudinal studies with a follow-up period of at least 10 years: a systematic review. Int J Oral Maxillofac Surg 2015;44:377-88.

2. Esposito M, Hirsch JM, Lekholm U, Thomsen P. Biological factors contributing to failures of osseointegrated oral implants. (II) Etiopathogenesis. Eur J Oral Sci 1998;106:721-764.

3. Esposito M, Grusovin MG, Maghaireh $H$, Worthington HV. Interventions for replacing missing teeth: different times for loading dental implants. Cochrane Database Syst Rev 2013;28: CD003878

4. Piattelli $A$, Pontes $A E$, Degidi $M$, lezzi G. Histologic studies on osseointegration: Soft tissues response to implant surfaces and components. A review. Dent Mater 2011;27:53-60.

5. Neer RM, Arnaud CD, Zanchetta JR, Prince R, Gaich GA, Reginster JY, et al. Effect of parathyroid hormone (1-34) on fractures and bone mineral density in postmenopausal women with osteoporosis. N Eng J Med 2001;344:1434-1441.

6. Arita S, Ikeda S, Sakai A, Okimoto N, Akahoshi S, Nagashima M, Nishida $A$, et al. Human parathyroid hormone (1-34) increases mass and structure of the cortical shell, with resultant increase in lumbar bone strength, in ovariectomized rats. J Bone Miner Metab. 2004;22:530540 .

7. Dobnig H, Turner RT. Evidence that intermittent treatment with parathyroid hormone increases bone formation in adult rats by activation of bone lining cells. Endocrinology. 1995;136:3632-3638.

8. Barros SP, Silva MA, Somerman MJ, Nociti FH Jr. Parathyroid Hormone Protects against Periodontitis-associated Bone Loss. J Dent Res 2003;82:791-795.

9. Shirota T, Tashie M, Ohno $K$, Yamaguchi A. Effect of intermittent parathyroid hormone (1-34) treatment on the bone response after placement of titanium implants into the tibia of ovarectomized rats. J Oral Maxillofac Surg 2003;61:471-480.

10. Skripitz R, Bohling $S$, Ruther W, Aspenberg P. Stimulation of implant fixation by parathyroid hormone (1-34) - A histomorphometric comparison of PMMA cement and stainless steel. J Orthop Res 2005;23:1266-1270.

11. Mohan S, Kutilek S, Zhang C, Shen HG, Kodama Y, Srivastava AK, et al. Comparison of bone formation responses to parathyroid hormone (1-34), (1-31), and (2-34) in mice. Bone 0ct 2000;27:471-478.

12. Mair B, Tangl S, Feierfeil J, Skiba D, Watzek G, Gruber R. Age-related efficacy of parathyroid hormone on osseointegration in the rat. Clin Oral Implants Res 2009; 20:400-405.

13. Vahle JL, Sato M, Long GG, Young JK, Francis PC, Engelhardt JA, et al. Skeletal changes in rats given daily subcutaneous injections of recombinant human parathyroid hormone (1-34) for 2 years and relevance to human safety. Toxicol Pathol 2002;30:312-321.

14. Jolette J, Wilker CE, Smith SY, Doyle N, Hardisty JF, Metcalfe AJ, et al. Defining a noncarcinogenic dose of recombinant human parathyroid hormone 1-84 in a 2-year study in Fischer 344 rats. Toxicol Pathol 2006;34:929-940.

15. Body JJ, Gaich GA, Scheele WH, Kulkarni PM, Miller PD, Peretz A, et al A randomized double-blind trial to compare the efficacy of teriparatide [recombinant human parathyroid hormone (1-34)] with alendronate in postmenopausal women with osteoporosis. J Clin Endocrinol Metab 
2002;87:4528-4535.

16. Maniatopoulos C, Rodriguez A, Deporter DA, Melcher AH. An improved method for preparing histological sections of metallic implants. Int J Oral Maxillofac Implants 1986;1:31-37.

17. Nociti Júnior FH, Cesar Neto JB, Carvalho MD, Sallum EA, Sallum AW. Intermittent cigarette smoke inhalation may affect bone volume around titanium implants in rats. J Periodontol 2002;73:982-987.

18. César-Neto JB, Duarte PM, Sallum EA, Barbieri D, Moreno H Jr, Nociti $\mathrm{FH}$ Jr. A comparative study on the effect of nicotine administration and cigarette smoke inhalation on bone healing around titanium implants. J Periodontol 2003;74:1454-1459.

19. Almagro MI, Roman-Blas JA, Bellido M, Castañeda S, Cortez R, HerreroBeaumont G. PTH [1-34] enhances bone response around titanium implants in a rabbit model of osteoporosis. Clin Oral Implants Res 2013;24:1027-1034

20. Lima LL, César Neto JB, Cayana EG, Nociti FH Jr, Sallum EA, Casati MZ. Parathyroid hormone (1-34) compensates the negative effect of smoking around implants. Clin Oral Implants Res 2013;24:1055-1059.

21. Tashjian AH Jr, Goltzman D. On the interpretation of rat carcinogenicity studies for human PTH(1-34) and human PTH(1-84). J Bone Miner Res 2008;23:803-811.

22. Subbiah V, Madsen VS, Raymond AK, Benjamin RS, Ludwig JA. Of mice and men: divergent risks of teriparatide-induced osteosarcoma. Osteoporos Int 2010;21:1041-1045.

23. Motyl KJ, McCauley LK, McCabe LR. Amelioration of type I diabetesinduced osteoporosis by parathyroid hormone is associated with improved osteoblast survival. J Cell Physiol 2012;227:1326-1334.

24. Takahata M, Schwarz EM, Chen T, O'Keefe RJ, Awad HA. Delayed shortcourse treatment with teriparatide (PTH(1-34)) improves femoral allograft healing by enhancing intramembranous bone formation at the graft-host junction. J Bone Miner Res 2012;27:26-37.

25. Thomas T. Intermittent parathyroid hormone therapy to increase bone formation. Joint Bone Spine 2006;73:262-269.

Received August 13, 2018 Accepted October 11, 2018 